\title{
PAPER ELECTROPHORESIS TECHNIQUE IN THE STUDY OF BIOLOGICALLY IMPORTANT BINARY COMPLEXES IN SOLUTION (THE SYSTEM BERYLLIUM(II) - AND COBALT(II) - NORVALINE)
}

\author{
B. B. TEWARI \\ Department of Chemistry, Faculty of Natural Sciences, University of Guyana, P. O. Box 101110, Georgetown, Guyana, South America.
} (Received: February 24, 2009 - Accepted: February 7, 2010)

\begin{abstract}
A new method paper electrophoresis, involving the use of a ionophoretic technique is described for the study of Be(II) and Co(II) biologically important binary complexes with norvaline in solution. The stability constants of $\mathrm{ML}$ and $\mathrm{ML}_{2}$ complexes of $\mathrm{Be}(\mathrm{II})$ - norvaline and $\mathrm{Co}(\mathrm{II})$ - norvaline systems have been found to be $(7.19 \pm 0.02,5.93 \pm 0.09)$ and $(4.61 \pm 0.12,2.83 \pm 0.05)$ (logarithm stability constant values), respectively at ionic strength of 0.1 mol L $\mathrm{L}^{-1}$ and a temperature of $35^{\circ} \mathrm{C}$
\end{abstract}

Keywords: Paper electrophoresis technique; Overall mobility; Beryllium(II) complexes; cobalt(II) complexes; Norvaline; stability constants.

\section{INTRODUCTION}

For the general case of the complex $\mathrm{ML}_{\mathrm{n}}$, the stepwise formation or stability constants $\left(\mathrm{K}_{\mathrm{n}}\right)$ are:

$$
\begin{aligned}
& \mathrm{M}+\mathrm{L} \quad \leftrightarrows \quad \mathrm{ML} \quad \mathrm{K}_{1}=\frac{\lfloor\mathrm{ML}\rfloor}{\lfloor\mathrm{ML}\rfloor[\mathrm{L}\rfloor} \\
& \mathrm{ML}+\mathrm{L} \quad \leftrightarrows \mathrm{ML}_{2} \quad \mathrm{~K}_{2}=\frac{\left\lfloor\mathrm{ML}_{2}\right\rfloor}{\lfloor\mathrm{ML}\rfloor[\mathrm{L}]} \\
& \mathrm{ML}_{2}+\mathrm{L} \quad \leftrightarrows \quad \mathrm{ML} \quad \mathrm{K}_{3}=\frac{\left\lfloor\mathrm{ML}_{3}\right\rfloor}{\left\lfloor\mathrm{ML}_{2}\right\rfloor\lfloor\mathrm{L}\rfloor} \\
& \mathrm{ML}_{\mathrm{n}-1}+\mathrm{L} \quad \leftrightarrows \quad \mathrm{ML} \quad \mathrm{K}_{\mathrm{n}} \quad=\frac{\left\lfloor\mathrm{ML}_{\mathrm{n}}\right\rfloor}{\left\lfloor\mathrm{ML}_{\mathrm{n}-1}\right\rfloor\lfloor\mathrm{L}\rfloor}
\end{aligned}
$$

where $\mathrm{M}$ and $\mathrm{L}$ are metal cation and ligand anion, respectively. For the calculation of total concentration of final complex product $\left(\mathrm{ML}_{\mathrm{n}}\right)$, the overall formation constant is used.

$$
\mathrm{b}_{\mathrm{n}}=\frac{\left[\mathrm{ML}_{\mathrm{n}}\right]}{[\mathrm{M}][\mathrm{L}]^{\mathrm{n}}}
$$

The overall formation constant is the product of stepwise formation constants

$$
\mathrm{b}_{\mathrm{n}}=\mathrm{K}_{1} \mathrm{~K}_{2} \mathrm{~K}_{3} \ldots \ldots \ldots \ldots \ldots \ldots \mathrm{K}_{\mathrm{n}}
$$

The inverse of formation constant, the dissociation constant $\mathrm{K}_{\mathrm{d}}$ is also sometime useful.

$$
\mathrm{ML} \quad \mathrm{D} \quad \mathrm{M}+\mathrm{L} \quad \mathrm{K}_{\mathrm{d}}=\frac{[\mathrm{M}][\mathrm{L}]}{[\mathrm{ML}]}
$$

$\mathrm{K}_{\mathrm{d}}$ has the same form as $\mathrm{K}_{\mathrm{a}}$ for acids, which facilities comparisons between metal complexes and BrÆnsted acids.

The complexation data involving body toxic or essential metal ions, bioactive ligand norvaline give insight into many physiochemical processes. The knowledge of the stabilities of mixed ligand complexes are known to play an important role in many metabolic and toxicological functions ${ }^{1}$. The beryllium and cobalt are toxic and essential metals respectively. Beryllium and cobalt are $2 \times 10^{-3}$ and $25 \mathrm{~g} / \mathrm{Kg}$ abundance in the Earth crust. Deficiency of cobalt cause anemic while excess cause coronary failure, thyroid dysfunction due to impaired accumulation of iodine. Inhaled beryllium compounds cause lung cancer. Beryllium inhibits phosphates enzymes and DNA replication. It is lethal at $1 \mathrm{ppm}$ of body weight ${ }^{2}$. Beryllium(II) and cobalt(II) are well known for its biomedical applications and toxicity ${ }^{3-20}$. Norvaline an amino acid $\mathrm{C}_{5} \mathrm{H}_{11} \mathrm{NO}_{2}$ isomeric with valine and usually made synthetically. It is not found in proteins. Norvaline has several significant applications in biological systems ${ }^{21-28}$. The present modified method is almost free from number of defects of common electrophoretic technique such as temperature during electrophoresis, capillary flow on paper, electroosmosis and adsorption. The technique is very convenient in use. It gives results in fair agreement with the accepted literature values.

Communication $^{29-32}$ from our laboratory described new method for the study of binary complexes. A search of literature indicated very few report on complexation of beryllium(II) and cobalt(II) with norvaline. In view of this attempt were made to establish the optimum conditions for metal(II) norvaline complexes formation. In addition, present paper describes a paper electrophoretic method for the determination of stability constants of these complexes.

\section{EXPERIMENTAL}

\section{Instruments}

Systronics (Naroda, India) paper electrophoresis equipment horizontalcum-vertical type, model 604, has been used. The apparatus consisted of a Polyethylene moulded double tank vessel. In our laboratory significant change in the instrument has been made. Two hollow rectangular plates covered with thin polythene sheets have been used through which thermosated water is run for controlling the temperature. The tanks were closed with a transparent Polyethylene moulded lid. The whole assembly is tight, which prevent moisture changes, which may upset the equilibria in a paper strip. This assembly design thus keeps to a minimum the disturbing effects of evaporation from the unwanted liquid flow in the paper. Each electrolyte tank contains a separate electrode chamber. The auxiliary unit is specially designed to operate either voltage mode or on current mode.

Elico (Hyderabad, India) model $\mathrm{L}_{110} \mathrm{pH}$ meter having glass and calomel electrode assembly and working on 220 Volts/ $50 \mathrm{~Hz}$ established a.c. mains, were employed for $\mathrm{pH}$ measurements.

Chemicals

Solutions of beryllium(II) and cobalt(II) metal perchlorate were prepared by preliminary precipitation of metal carbonates from $0.1 \mathrm{Mol} \mathrm{L}^{-1}$ solution of sodium carbonate (chemically pure grade, BDH, Poole, UK), which were washed with boiling water and treated with calculated amounts of $1 \%$ Analytical-Reagent grade perchloric acid. These were boiled on a water bath and filtered. The metal contents of the filtrates were determined and final concentration kept at $5.0 \times 10^{-3} \mathrm{Mol} \mathrm{L}^{-1}$.

A $0.1 \%(\mathrm{~W} / \mathrm{V})$ solution of $1-(2$-pyridylazo $)-2-$ naphthol (PAN) (E. Merck, Darmstadt, Germany) in ethanol was used for detecting the metal ions. $0.005 \mathrm{Mol} \mathrm{L}^{-1}$ glucose (BDH, Analytical - Reagent grade) solution was prepared in water and used as an electro-osmotic indicator for the correction due to electro-osmosis. A saturated aqueous $(0.9 \mathrm{ml})$ solution of silver nitrate was diluted with acetone to $20 \mathrm{~mL}$. Glucose was detected by the spraying with this silver nitrate solution and then with $2 \%$ ethanolic solution of sodium hydroxide, when a black spot was formed.

\section{Background Electrolytes}

Stock solution of $5.0 \mathrm{Mol} \mathrm{L}^{-1}$ perchloric acid was prepared by its $70 \%$ solutions (SDS, Analytical - Reagent grade). $2.0 \mathrm{Mol} \mathrm{L}^{-1}$ sodium hydroxide 
(Analytical Reagent grade) and $0.5 \mathrm{Mol} \mathrm{L}^{-1}$ norvaline (BDH, Poole, UK) solutions were prepared. All chemicals were used without further purifications. Each solution was standardized using the appropriate method. The background electrolytes used in the study of binary complexes were $0.1 \mathrm{Mol} \mathrm{L}^{-1}$ perchloric acid and $0.01 \mathrm{Mol} \mathrm{L}^{-1}$ norvaline. The system was maintained at various $\mathrm{pH}$ by the addition of sodium hydroxide.

Procedure

Whatman No. 1 filter paper for chromatography was used for the purpose of electrophoresis. For recording observation of particular metal ion, two strips were spotted with the metal ion solution along with additional two spotted with glucose using $1.0 \mu \mathrm{L}$ pipette and then mounted on the insulated plate. Each of the two electrolyte vessel was filled with $150 \mathrm{~mL}$ of background electrolyte containing $0.1 \mathrm{Mol} \mathrm{L}^{-1}$ perchloric acid and $0.01 \mathrm{Mol} \mathrm{L}^{-1}$ norvaline. The paper becomes moistened with the background electrolyte solutions due to diffusion. The second insulated plate was placed on paper strips and then thermostated water $\left(35^{\circ} \mathrm{C}\right)$ was circulated in the plates to keep the temperature constant. The lid was then placed on the instrument to make it air tight. It was left for 10 minutes to insure wetting of strips. Subsequently a direct 200 Volts potential was applied between the electrodes. Electrophoresis was carried for 60 minutes after which these strips were removed from the tank and dried. The metal ion and glucose spots were detected by specific reagents. The leading and tailing edge were measured from the marked centre point and the mean were taken. The distance moved by glucose was subtracted (in case of migration toward anode) to obtain correct path length. Migration towards anode and cathode were designated by negative and positive signs respectively.

Electrophoretic observations on metal ions were recorded at various $\mathrm{pH}$ values of the background electrolyte obtained by adding $\mathrm{NaOH}$ solution. The ionic strength being maintained at $0.1 \mathrm{Mol} \mathrm{L}^{-1}$. The observed mobility of migrant was calculated by using the formula.

$$
\mathrm{U}=\frac{\mathrm{d}}{\mathrm{x} \cdot \mathrm{t}}
$$

After applying the correction factor the observed mobility is given as

$$
\mathrm{U}=\frac{\mathrm{d} \pm \mathrm{d}_{\mathrm{G}}}{\mathrm{x} \cdot \mathrm{t}}
$$

Where $U=$ mobility of metal ion/complex ion; $\mathrm{d}=$ mean of duplicate distance travelled by metal ion/complex ion; $\mathrm{d}_{\mathrm{G}}=$ mean of duplicate distance travelled by glucose spot; $\mathrm{x}=$ field strength; $\mathrm{t}=$ time for electrophoresis

The protonation constants of pure norvaline were determined by the same paper electrophoresis technique. The two paper strips were spotted with pure norvaline along with two glucose using $0.1 \mathrm{Mol} \mathrm{L}^{-1}$ perchloric acid only in a background electrolyte. The electrophoretic speed was calculated and the speed of the metal ion/norvaline spots are reported with $\mathrm{pH}$ values. The individual speeds of the duplicate spots were found to be fairly equal.

\section{RESULTS}

Chemical literature ${ }^{33-36}$ confirms that anionic species of amino acids are the sole ligating species for metal ions. The electrophoretic mobility of the metal spot against $\mathrm{pH}$ gives a curve with number of plateus is shown in Figure 1. A constant speed over a range of $\mathrm{pH}$ is possible only when a particular complex species is overwhelmingly formed. Thus, every plateau is indicative of formation of a certain complex species. The first one in the beginning corresponds to a region in which metal ions are uncomplexed. In this region of low $\mathrm{pH}$, concentration of unprotonated species of norvaline $\left[\mathrm{CH}_{3} \mathrm{CH}_{2} \mathrm{CH}_{2} \mathrm{CH}\right.$ $\left.\left(\mathrm{NH}_{3}^{+}\right) \mathrm{COOH}\right]$ is maximum and this species is non-complexing, beyond this range, metal ions spots have progressively decreasing mobility, complexation of metal ions should be taking place with anionic species of norvaline, whose concentration increases progressively with increase of $\mathrm{pH}$. Figure 1 shows three plateaus in both $\mathrm{Be}(\mathrm{II})$ and $\mathrm{Co}(\mathrm{II})$, hence both metal ions form two complexes with norvaline anion. Prominent chelating properties have also been assigned to unprotonated anionic species of norvaline, ruling out any such property to the zwitterions ${ }^{37,38}$.

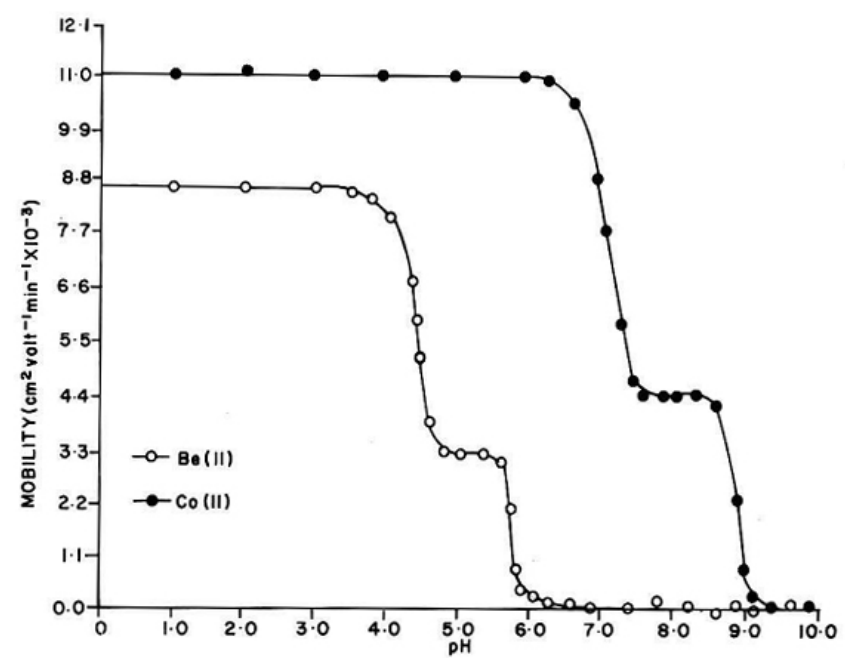

Figure 1: Mobility curves for the metal(II) - norvaline complexes. $=\mathrm{Be}(\mathrm{II})-$ norvaline; $\cdot=\mathrm{Co}(\mathrm{II})-$ norvaline. Background electrolytes $=0.1$ Mol L-1 perchloric acid and $0.01 \mathrm{Mol} \mathrm{L}^{-1}$ norvaline. Concentration of $\mathrm{Be}(\mathrm{II})$ and $\mathrm{Co}(\mathrm{II})=0.005 \mathrm{Mol} \mathrm{L}^{-1}$. Variation in the $\mathrm{pH}$ was made by the addition of sodium hydroxide.

Figure 1 discloses that $\mathrm{Be}(\mathrm{II})$ and $\mathrm{Co}(\mathrm{II})$ metal ions form their first complex movement towards negative electrode. Hence one anionic species of norvaline $\left[\mathrm{CH}_{3} \mathrm{CH}_{2} \mathrm{CH}_{2} \mathrm{CH}\left(\mathrm{NH}_{2}\right) \mathrm{COO}^{-}\right]$, must have combined with $\mathrm{Be}$ (II) and $\mathrm{Co}$ (II) metal ions to give 1:1 [Be $\left.\left\{\mathrm{CH}_{3} \mathrm{CH}_{2} \mathrm{CH}_{2} \mathrm{CH}\left(\mathrm{NH}_{2}\right) \mathrm{COO}\right\}\right]$ and $\left[\mathrm{Co}\left[\mathrm{CH}_{3} \mathrm{CH}_{2}\right.\right.$ $\left.\left.\mathrm{CH}_{2} \mathrm{CH}\left(\mathrm{NH}_{2}\right) \mathrm{COO}\right\}\right]^{+}$, complex cations, respectively. The third plateau in each case is due to 1:2 metal - ligand complex. Hence, two anionic species of norvaline $\left[\mathrm{CH}_{3} \mathrm{CH}_{2} \mathrm{CH}_{2} \mathrm{CH}\left(\mathrm{NH}_{2}\right) \mathrm{COO}^{-}\right]$, must have combined with $\mathrm{Be}(\mathrm{II})$ and $\mathrm{Co}$ (II) to give 1:2 [Be $\left.\left\{\mathrm{CH}_{3} \mathrm{CH}_{2} \mathrm{CH}_{2} \mathrm{CH}\left(\mathrm{NH}_{2}\right) \mathrm{COO}\right\}_{2}\right]$, and [Co $\left\{\mathrm{CH}_{3}\right.$ $\left.\mathrm{CH}_{2} \mathrm{CH}_{2} \mathrm{CH}\left(\mathrm{NH}_{2}\right) \mathrm{COO}\right\}_{2}$, neutral metal complexes, respectively.

Further increase of $\mathrm{pH}$ has no effect on the mobility of metal ions, which indicates no further interaction between metal ions and ligands. The complexation of metal ions with norvaline anion may be represented as:

$$
\begin{aligned}
& k_{1} \\
& \mathrm{M}^{2+}+\mathrm{L}_{\mathrm{K}_{2}}^{\underset{\mathrm{K}}{\leftrightarrows}} \mathrm{ML}^{+} \\
& \mathrm{ML}^{+}+\mathrm{L}^{-} \leftrightarrows \quad \mathrm{ML} 2
\end{aligned}
$$

here $\mathrm{M}^{2+}=\mathrm{Be}^{2+}$ and $\mathrm{Co}^{2+}$ metal cations; [ $\left.\mathrm{L}^{-}\right]=$norvaline anion; $\mathrm{K}_{1}$ and $\mathrm{K}_{2}$ are the first and second stability constants respectively. The metal spot on the paper is thus a combination of uncomplexed metal ions, 1:1 and 1:2 metal complexes. The spot is moving under the influence of electric field, if nonprotonated and protonated species are considered, the overall mobility can be given by expression.

$$
\begin{aligned}
& \mathrm{U}_{0,0} \cdot \beta_{0,0}+\mathrm{U}_{1,0} \cdot \beta_{1,0}[\mathrm{~L}]+\mathrm{U}_{2,0} \cdot \beta_{2,0}[\mathrm{~L}]^{2}+\cdots \\
& \mathrm{U}_{1,1} \cdot \beta_{1,1}[\mathrm{HL}]+\mathrm{U}_{2,1} \cdot \beta_{2,1}[\mathrm{HL}]^{2}+\cdots \\
& \mathrm{U}_{2,1} \cdot \beta_{2,1}\left[\mathrm{H}_{2} \mathrm{~L}\right]+\mathrm{U}_{2,2} \cdot \beta_{2,2}\left[\mathrm{H}_{2} \mathrm{~L}\right]^{2}+\cdots--\cdot-\cdot- \\
& \mathrm{U}^{=} \\
& \beta_{0,0}+\beta_{1,0}[\mathrm{~L}]+\beta_{2,0}[\mathrm{~L}]^{2}+\beta_{1,1}[\mathrm{HL}] \\
& +\beta_{2,1}[\mathrm{HL}]^{2}+\beta_{1,2}\left[\mathrm{H}_{2} \mathrm{~L}\right] \\
& +\beta_{2,2}\left[\mathrm{H}_{2} \mathrm{~L}\right]^{2}+------
\end{aligned}
$$

where $\mathrm{U}_{0,0}$ is the speed of uncomplexed metal ion, $\mathrm{U}_{1,0}$ is the speed of complex formed by the combination of one unprotonated anionic ligand with metal ion and $\mathrm{U}_{\mathrm{x}}$ is the speed of the metal complex formed by the combination of $\mathrm{X}$ anions containing p protons each. b's are the overall stability constant of the different equilibria above equation transformed into following useful form ${ }^{39}$.

$$
\mathrm{U}=\frac{\mathrm{u}_{0}+\mathrm{u}_{1} \mathrm{~K}_{1}\left[\mathrm{~L}^{-}\right]+\mathrm{u}_{2} \mathrm{~K}_{1} \mathrm{~K}_{2}\left[\mathrm{~L}^{-}\right]^{2}}{1+\mathrm{K}_{1}\left[\mathrm{~L}^{-}\right]+\mathrm{K}_{1} \mathrm{~K}_{2}\left[\mathrm{~L}^{-}\right]^{2}}
$$

here $\mathrm{u}_{0}, \mathrm{u}_{1}, \mathrm{u}_{2}$ mobilities of the uncomplexed metal ions, 1:1 and 1:2 metal 
complexes, respectively. The protonation constants of pure norvaline $\left(\mathrm{pKa}_{1}=\right.$ $\left.2.31, \mathrm{pKa}_{2}=9.65\right)^{40}$ were determined by same paper ionophoretic technique. The mode of deprotonation of pure norvaline can be represented as:

$$
\left[\mathrm{CH}_{3} \mathrm{CH}_{2} \mathrm{CH}_{2} \mathrm{CH}\left(\mathrm{NH}_{3}{ }^{+}\right) \mathrm{COOH}\right]
$$

$$
\mathrm{pKal} \quad \downarrow \uparrow \quad-H^{+}
$$

\section{$\left[\mathrm{CH}_{3} \mathrm{CH}_{2} \mathrm{CH}_{2} \mathrm{CH}\left(\mathrm{NH}_{3}{ }^{+}\right) \mathrm{COO}^{-}\right]$}

$$
\mathrm{pK}_{\mathrm{a} 2} \quad \downarrow \uparrow \quad-\mathrm{H}^{+}
$$

\section{$\left[\mathrm{CH}_{3} \mathrm{CH}_{2} \mathrm{CH}_{2} \mathrm{CH}\left(\mathrm{NH}_{2}\right) \mathrm{COO}^{-}\right]$}

Using protonation constants of pure norvaline the concentration of norvaline anion $\left[\mathrm{L}^{-}\right]$is determined for the $\mathrm{pH}$ value(s) of interest, from which $\mathrm{K}_{1}$, can be calculated. The concentration of complexing norvaline anion [ $\left.\mathrm{L}^{-}\right]$is calculated with the help of equation.

$$
\left[\mathrm{L}_{\mathrm{T}}\right]
$$

$$
1+[\mathrm{H}] / \mathrm{pKa}_{2}+[\mathrm{H}]^{2} / \mathrm{pKa}_{1} \cdot \mathrm{pKa}_{2}
$$

here $\left[\mathrm{L}_{\mathrm{T}}\right]=$ total concentration of ligand norvaline $\left[0.001 \mathrm{Mol} \mathrm{L}^{-1}\right]$, $\mathrm{pKa}_{1}$ and $\mathrm{pKa}_{2}=$ first and second protonation constant of pure norvaline, respectively.

For calculating first stability constant, $\mathrm{K}_{1}$, the region between first and second plateau is pertinent. The overall mobility will be equal to the arithmetic mean of the mobility of uncomplex, $\mathrm{u}_{0}$, and that of first complex, $\mathrm{u}_{1}$, at a $\mathrm{pH}$ value where $\mathrm{K}_{1}=1 /\left[\mathrm{CH}_{3} \mathrm{CH}_{2} \mathrm{CH}_{2} \mathrm{CH}\left(\mathrm{NH}_{2}\right) \mathrm{COO}^{-}\right]$.

The second stability constant $\mathrm{K}_{2}$, of 1:2 complex can be calculated by taking into consideration, the region between second and third plateau of mobility curve. The (Se) calculated value of $\mathrm{K}_{1}$ and $\mathrm{K}_{2}$ are given in Table 1 .

Table 1: Stability constants of the binary complexes of beryllium(II) and cobalt(II) with norvaline.

\begin{tabular}{|c|c|c|c|}
\hline $\begin{array}{c}\text { Metal } \\
\text { Ions }\end{array}$ & Complexes & $\begin{array}{c}\text { Stability } \\
\text { constants }\end{array}$ & $\begin{array}{c}\text { Logarithm } \\
\text { stability } \\
\text { constant values }\end{array}$ \\
\hline \multirow{2}{*}{$\mathrm{Be}^{++}$} & $\mathrm{ML}^{+}$ & $\mathrm{K}_{1}$ & $7.19 \pm 0.02$ \\
\cline { 2 - 4 } & $\mathrm{ML}_{2}$ & $\mathrm{~K}_{2}$ & $5.93 \pm 0.09$ \\
\hline \multirow{3}{*}{$\mathrm{Co}^{++}$} & $\mathrm{ML}^{+}$ & $\mathrm{K}_{1}$ & $\begin{array}{c}4.61 \pm 0.12 \\
(4.29) 40^{*}\end{array}$ \\
\cline { 2 - 4 } & $\mathrm{ML}_{2}$ & $\mathrm{~K}_{2}$ & $\begin{array}{c}2.83 \pm 0.05 \\
(3.62) 40^{*}\end{array}$ \\
\hline
\end{tabular}

Ionic strength $=0.1 \mathrm{Mol} \mathrm{L}^{-1} ;$ temperature $=35^{\circ} \mathrm{C} ; \mathrm{M}=$ metal cations $\left(\mathrm{Be}^{++}\right.$ and $\mathrm{Co}^{++}$);

$\mathrm{L}=$ ligand (norvaline); norvaline anion: $\left[\mathrm{CH}_{3} \mathrm{CH}_{2} \mathrm{CH}_{2} \mathrm{CH}\left(\mathrm{NH}_{2}\right) \mathrm{COO}\right]$

* Literature values are given in the bracket.

\section{DISCUSSION}

The order of stability constant values viz:

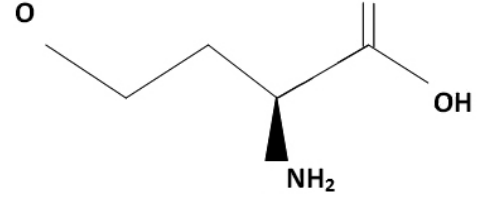

beryllium(II) $>$ cobalt(II)

are found in support from the work of Irving and Williams ${ }^{41}$. Comparison of the stability constants shows that values are lower in second complexes. It is therefore inferred that the coordinating tendency of a ligand decreases with higher state of aggregation. In other words, the metal progressively lessen its tendency of linkage with a ligand on progressive filling of vacant orbitals. This conclusion is of universal validity as evident in chemical literature ${ }^{42}$. Higher stability constants values of beryllium(II) - norvaline complexes indicate greater affinity of beryllium(II) with oxygen donor ligands.

The molecular structure of norvaline is given as

$$
\text { S1. Structure of norvaline }
$$

It is observed from the Table 1 that calculated stability constant values are approximately similar to literature values. The slight divergence in the values obtained from different sources is mainly due to the difference in temperatures and ionic strength used by different sources. The precision of the method is limited to that of paper electrophoretic technique. Nevertheless in view of the uncertainty $\pm 5 \%$ attending to the measurement of the mobility of the metal spots, the results reported are fairly reliable.

To examine the possibility of hydrolysis of $\mathrm{Be}(\mathrm{II})$ at higher $\mathrm{pH}$ experiments have been performed at two concentrations of the ligand (norvaline) $0.01 \mathrm{Mol}$ $\mathrm{L}^{-1}$ and $0.001 \mathrm{Mol} \mathrm{L}^{-1}$. The mobility curves show that the plateaus at lower ligand concentration are shifted towards higher $\mathrm{pH}$ range but the calculated stability constants values are found to be the same in the two cases. Thus the constant obtained is in dependent of the $\mathrm{pH}$ indicating the hydrolysis of Beryllium(II) can be ignored here.

\section{CONCLUDING REMARKS}

Following conclusions can be shown from the present study.

1. Beryllium(II) and cobalt(II) are significant for biological systems but as such they are toxic, the norvaline may be used to reduce the level of these metal ions in the biological systems.

2. Beryllium(II) and cobalt(II) are toxic and essential metal ions respectively.

3. Beryllium(II) - norvaline complexes have high stability constant values in comparison to cobalt(II) - norvaline complexes.

4. The present paper electrophoretic technique is very helpful in finding that complex system is formed or not, if formed its stability constants can also be determined.

5. Biologically important beryllium(II) and cobalt(II) complexes with norvaline can be prepared on large scale at particular $\mathrm{pH}$ of the background electrolyte.

6. $\mathrm{ML}_{2}$ complexes are found to have low stability constant value and less stable in comparison to ML complexes.

7. Stability constants of metal complexes can be very easily calculated by this technique, so the present paper electrophoretic technique has significant advantages over the other physiochemical methods reported in chemical literature for the determination of stability constants of metal complexes.

\section{REFERENCES}

1. M. T. Beack, Chemistry of Complex, Equilibria, Van Nostrand, London, 1970.

2. D. Banerjea, Everyman's Sci., 29 (6), 176 (1995).

3. R. Wegner, R. Heinrich - Ramm, D. Nowak, K. Olma, B. Poschadel and D. Szadkowski, Occup. Environ. Med., 57, 133 (2000).

4. P. Gili and A. Mederos, J. Mex. Chem. Soc., 44 (2), 104 (2000).

5. R. T. Sawyer, D. R. Dobis, M. Goldstein, L. Velsor, L. A. Maier, A. P. Fontenot, L. Silveira, L. S. Newman and B. J. Day, Free Radical Biol. Med., 38, 928 (2005).

6. A. Johnson and P. Schredders, Eur. J. Eng. Edu., 28(1), 37 (2003). 
7. S. Franzie and B. Markert, Environ. Pollut., 120(1), 27 (2002).

8. L. S. Newman, M. M. Mroz, L. A. Maier, E. M. Daniloff and R. Balkissoon, J. Occup. Environ. Med., 43(3), 231 (2001).

9. Z. Wang, G. M. Farris, L. S. Newman, Y. Shou, L. A. Maier, H. N. Smith and B. L. Marrone, Toxicol., 165(1), 27 (2001).

10. J. -Q. Zhao, G.-Z. Du, Y.-C. Xiong, Y.-F. Wen, M. Bhadauria and S. K. Nirala. Arch. Pharm. Res., 30(12), 1575 (2007).

11. W. Yang, G. Yang, Q. Hu, J. Yin and G. Xie, S. Afr. J. Chem 2 59, 17 (2006).

12. K. O. Ogunniran, A. C. Tella, M. Alensela and M. T. Yakubu, Afr. J. Biotechnol., 6(10), 1202 (2007).

13. N. Dirilgen, Turk J. Chem., 25, 173 (2001).

14. M. Namiecinska, A. Wiktorowska - Owczarek, A. Loboda, J. Dulak and J. Z. Nowak, Pharm. Rep., 58, 884 (2006).

15. D. Baralkiewicz and J. Siepak, Polish J. Environ. Stud., 8(4), 201 (1999).

16. E. Benzamin III, A. Reznik, E. Benzamin and A. L. Williams, Int. J. Environ. Res. Public Health, 4(3), 203 (2007).

17. M. A. Saito, G. Rocap and J. W. Moffett, Limnol Oceanogr., 50(1), 279 (2005).

18. E. E. Aziz, G. Nadia and M. B. Nadia, Aust. J. Basic Appl. Sci., 1(2), 73 (2007).

19. H. R. Pouretedal and M. Asafi, J. Iran Chem. Soc., 4(4), 503 (2007).
20. M. Gibczynska, E. Meller, S. Stankowski and Cz. Woloszyk, Agron. Res., 4(2), 509 (2006).

21. I. Woznica, W. Szeszel-Fedarowicz and G. Rosinski, Acta Biochemica Polinica, 51(1), 115 (2004).

22. J. P. Collman, L. Fu, P. C. Herrmann and X. Zhang, Science, 275(5302), 949 (1997)

23. N. Ahned and P. J. Thomalley, Biochem. Soc. Trans., 31, 1417 (2003).

24. C. - I. Chang, J. C. Liao and L. Kuo, Canc. Res., 61, 1100 (2001).

25. H. Okada, K. Yamamoto, S. Tsutano and S. Nakamura, J. Antibiot., 41(7), 869 (1988).

26. I. Nagypal and A. Gergely, J. Chem. Soc. Dalton Trans., 1109 (1977).

27. F. R. Whatley, Phil. Trans. R. Soc. Lond. A., 363, 611 (1981).

28. W. G. Boll, Nature, 174, 517 (1954).

29. B. B. Tewari, Trans. SAEST, 30(2), 76 (1995).

30. B. B. Tewari, J. Indian Chem. Soc., 75, 91 (1998)

31. B. B. Tewari, J. Electrochem. Soc. India, 43(2) 111 (1994).

32. B. B. Tewari, J. Indian Chem. Soc., 73, 349 (1996).

33. J. A. Carty and J. N. Taylor, Inorg. Chem., 16, 177 (1977).

34. W. Levason, A. C. McAuliffle and M. D. Johus, Inorg. Nucl. Chem. Lett., 13, 123 (1977).

35. K. W. Musher and H. C. Neagley, Inorg. Chem., 14, 1728 (1975).

36. Y. Hoja, Y. Sugiura and H. Tanaka, J. Inorg. Nucl. Chem., 39, 1859 (1977)

37. J. J. Christensen, J. L. Oscarson and R. M. Izatt, J. Am. Chem. Soc., 90, 5949 (1968).

38. J. F. Thiers, L. C. Van Poucke, and M. A. Herman, J. Inorg. Nucl. Chem., 30, 1543 (1968).

39. D. L. Robenstien and R. J. Kule, J. Am. Chem. Soc., 91, 2492 (1969).

40. A. E. Martell and R. M. Smith, Critical Stability Constants, Amino Acids, Plenum Press, New York, 1, 7 (1974).

41. H. Irving and R. William, Nature, 162, 746 (1948).

42. J. D. Joshi, Indian J. Chem., 21, 446 (1982). 